\title{
THE GLOBALIZATION IMPACT ON CREATIVE INDUSTRIES AND CULTURAL HERITAGE: A CASE STUDY
}

\author{
Cristian CIUREA ${ }^{1, *}$, Florin Gheorghe FILIP $^{2}$ \\ ${ }^{1}$ Bucharest Academy of Economic Studies, Faculty of Economic Cybernetics, Statistics and Informatics, \\ Department of Economic Informatics and Cybernetics, Piata Romana no. 6, 010374, Bucharest, Romania \\ ${ }^{2}$ Romanian Academy, Section for Information Science and Technology, \\ Calea Victoriei no. 125, 010071, Bucharest, Romania
}

Received 16 January 2019; accepted 1 July 2019

\begin{abstract}
The influences of multiculturalism, globalization and technological revolution on art galleries, libraries, archives, museums have led to major changes in the way they select, preserve, promote and valorize their cultural goods. The digitization of cultural heritage collections and the evolution of information technologies (cloud computing, mobile devices, Internet of things) have determined the progress of virtual exhibitions as a means of promoting and valorizing the cultural heritage physical objects. New business models have been developed to harness the cultural heritage of libraries and museums in the context of globalization and technological revolution and the premises for the development of a new category of entrepreneurs have been created. Studies have been conducted to find the ways to increase the number of visitors of cultural institutions with the help of promoting tools, such as virtual exhibitions and dedicated mobile applications. The paper presents several methodological aspects and conclusions based on a practical example.
\end{abstract}

Keywords: cultural heritage, cultural institutions, globalization, information and communications technology, valorization, virtual exhibitions.

\section{Introduction}

Nowadays, modern information and communications technologies (ICTs) enable the people to travel and explore in an easier and more comfortable way than it was possible a few years ago. The human being has always been mobile and has, throughout history, interacted with other humans, tribes, and nations. As a traveler, the man plays an important role in the diffusion and creation of new ideas, views and attitudes, and this can be considered to be the initial seeds of a potentially global culture (GC). Globalization includes, by default, different topics, such as economics, politics, identity and culture, as well as citizenship. A new concept appeared as a connection between globalization and culture and this is the "world citizenship" ("WC"). It is interesting to discover that the expression "WC" is often mentioned in connection to other issues related on globalization (Vesajoki, 2002).

${ }^{\star}$ Corresponding author. E-mail: cristian.ciurea@ie.ase.ro

This is an Open Access article distributed under the terms of the Creative Commons Attribution License (http://creativecommons. org/licenses/by/4.0/), which permits unrestricted use, distribution, and reproduction in any medium, provided the original author and source are credited. 
In the context of WC and GC, it has become a more difficult task to retrieve and distinguish the cultural identity of a specific nation. Some countries have tried to preserve their own cultural identity, and they have promoted the most attracting cultural objects that represent their own identity. We already associate well-known cities around the world with specific cultural objects, such as sculptures, paintings, monuments, and so on. For example, Tour Eiffel or Mona Lisa (artist Leonardo da Vinci, 1503) portrait are connected with Paris, Colosseum with Rome and so on.

Due to the development of mobile devices and technologies (now we have the best maps in the world), the decrease in costs brought on by air-travel market liberalization and the increase of accommodations and bookings via dedicated platforms, the concept of "overtourism" appeared. Now, it is mandatory for cultural institutions to bring their collections online, as digital assets, in order to retrieve information from historical data collections and disseminate the memory of cultural heritage $(\mathrm{CH})$.

The economic development is an important factor that stimulates and is stimulated by the cultural development of a country. The culture is both stable and changeable, depending on the economic development. As a country gets richer, it will experience significant cultural changes in all activity fields (Minkov, 2011). The Inglehart-Welzel cultural map of the world is a scatter plot created by the scientists Ronald Inglehart and Christian Welzel (World Values Survey, 2014) based on the World Values Survey that depicts closely linked cultural values that vary between societies in two predominant dimensions. On the vertical y-axis traditional versus secular-rational values are represented. Survival versus self-expression values are represented on the horizontal x-axis. Moving upwards on this map reflects the shift from traditional values to secular-rational ones and moving rightwards represents the shift from survival values to self-expression values.

The permanent problem of globalization, in which great cultural models replace smaller and weaker ones similar to the process of internationalization of cultures, is generally defined as the acculturation or cultural colonization, meaning to turn the one's culture into somebody else's (Šola, 2018). The "cultural economy" concept was previously analyzed by the authors in Florin Gheorghe Filip, Cristian Ciurea, Horațiu Dragomirescu, and Ion Ivan (2015) and in Filip, Constantin-Bălă Zamfirescu, and Ciurea (2017), together with a possible business model (BM) to describe the relationships between $\mathrm{CH}$ institutions, access facilitators and culture consumers.

The modern ICTs have a significant impact on the dissemination of cultural collections (CCs) in the 21 st century. The influence of modern ICTs on creative economy and creative society is described by Tomas Kačerauskas (2015). The information technologies are very strongly connected with creative activities, and, at the same time, the development of existing technologies and releasing new ones need creativity.

Taking into consideration that a small part of the European $\mathrm{CH}$ collections has been digitized until now and the largest part should be digitized in the next few years, the digitization level of heritage collections was considered as an indicator of soft innovation in the cultural sector, enhanced by the digital literacy at the level of producers and consumers of cultural goods, as presented by Karol J. Borowiecki and Trilce Navarrete (2017). The concept of democratization of heritage through digital access is presented by Joel Taylor and Laura 
Kate Gibson (2017) and the digitization and social media are considered to have a significant role in terms of whose $\mathrm{CH}$ collections are accessible. The digitization process of CCs is very important not only to ensure the long-term preservation of special and rare manuscripts, documents, seals, paintings, and so on, but also to create digital content of online exhibitions, virtual museums (VMs) and other multimedia representations of CCs, to enhance their promotion and valorization.

The smart museum (SM) or thinking museum represents the ICT-enabled way in the current world to make known the CCs, as described in Tomislav Šola (2018). The concept of SM is significantly different from digital museum, because it should be based on technologies, such as big data, Internet of things, and cloud computing. The SM should include, besides digitizing the collections, other three dimensions, such as smart management, smart conservation and smart services for the visitors (Spohrer, 2018; Maglio \& Spohrer, 2008).

Before starting projects to apply ICTs in cultural institutions (CIs), a sound decision would be to analyze the ongoing processes and find answers to a set of several practical questions, such as: a) "What the other do?", b) "Which are the most adequate ICTs tools utilized?", c) "What is direct and indirect impact of such an undertaking and how to measure the soundness and profitability of the efforts?". This paper aims at presenting several preliminary answers to the above questions by using empirical data collected from a particular virtual exhibition (VE) entitled Ferdinand I. The data collected based on Google Analytics are used to measure the visitors' behavior in the VE and their expectations from such an application.

\section{Virtual exhibitions - tools for promotion and valorization of cultural collections}

The CIs, such as galleries, libraries, archives and museums, are not only knowledge depositaries through the preservation of $\mathrm{CH}$ collections, but are also knowledge creators with the help of modern ICTs, as described by Ciurea and Filip (2018).

According to Smithsonian Institution (2002), a CI can implement a variety of physical exhibition (PHE) types, such as:

- exhibition as artefact display;

- exhibition as communicator of ideas;

- exhibition as visitor activity;

- exhibition as environment.

The particular type of experience that a visitor reports enjoying a PHE depends on the individual himself/herself, the particular visit, and the content the CIs offer. Certain types of experiences have come to be associated to a greater extent with some CIs than others. For example, some visitors are almost equally interested in object experiences, such as seeing rare and uncommon things, and also in learning experiences (the Smithsonian Institution, 2002).

One of the technology evolution benefits is the possibility to create digital copies of cultural objects through digitization. These copies have many advantages, such as the preservation of physical copies that can be destroyed during the manipulation, and the opportunity to deliver the cultural content to the public via Internet on multiple devices and in different ways. 
Regarding the digitization of $\mathrm{CH}$ collections, it should be mentioned that only $10 \%$ of overall collections from European CIs have been digitized. The remaining $90 \%$ should be digitized in the next few years, in a hasty manner, because Europe has realized that the $\mathrm{CH}$ can be exploited as a strategic economic resource (Digital Single Market, 2019; Ciurea \& Filip, 2018).

When discussing advanced digitization (AD), it will be taken into account the scanning and photographing of the CCs at a high resolution, in order to ensure the best quality of digital copies.

The AD will play a significant role in the development of active digital resources that shall stimulate the economic development of creative industries and shall have a scientific impact on CIs. This will lead to a better promotion of Europe's $\mathrm{CH}$.

The concept of VEs appeared, simulating the visitor's experiences from a PE, but in a virtual environment, accessed with the help of a computer or a mobile device (MD), because VEs can be implemented as web applications or as native mobile applications. After the upload of digital documents in the database of a VE, the users will have the possibility to explore digital images in detail, by applying zoom tools, so that to discover particular elements which they cannot see when navigating through the physical documents.

The development and implementation of VEs have as first objective to promote and valorize the $\mathrm{CH}$ from $\mathrm{CIs}$ and, after that, to attain other secondary objectives, such as attracting new visitors or increasing the public interest in some specific collections (Ciurea \& Filip, 2016).

Considering the recent progress in technology, we can combine VEs, implemented on computers or on MDs, with other hardware and software functionalities, such as VEs seen through virtual reality glasses or augmented reality combined with physical cultural objects. The more visitors are involved in the exploration of VE collections, the more attractive the exhibition is.

In the near future, the implementation of a standalone VM with automatic ticketing and customized cultural content delivery will be possible, in order to offer to each visitor exactly the information that he needs.

The usage of biometric technologies for virtual electronic meetings, as described in Filip et al. (2017), can be adapted and applied also in the case of VEs when dealing with users' authentication and measuring the user' behavior in the application. In order to analyze the visitors' experience in a VE, each visitor should authenticate himself/herself in the application. In the case of a VE implemented as a native mobile application, the authentication can be performed using fingerprint recognition.

\section{Cultural data analysis at European level}

Based on data collected from two sources (museums.eu: The European Museums Network, 2019b; Eurostat, 2019), we have performed an analysis of the number of permanent and temporary exhibitions (PTEs) created by each European country and the percent of cultural participation (CP) (meaning the percent of population aged 16 and over that participated at least one time in the last year at a cultural event). The data collected are presented in Table 1. 
Table 1. Number of permanent and temporary exhibitions and cultural participation per country (source*: museums.eu: The European Museums Network, 2019a; Eurostat, 2018; created by authors)

\begin{tabular}{|c|c|c|c|}
\hline Country & $\begin{array}{l}\text { Number of permanent } \\
\text { exhibitions }^{*}\end{array}$ & $\begin{array}{l}\text { Number of temporary } \\
\text { exhibitions }{ }^{\star}\end{array}$ & $\begin{array}{c}\text { Cultural participation } \\
\text { (\% of population aged } \\
16 \text { and over })^{* *}\end{array}$ \\
\hline Austria & 22 & 122 & 74 \\
\hline Belgium & 1 & 15 & 68 \\
\hline Bosnia and Herzegovina & 5 & 33 & 24 \\
\hline Bulgaria & 3 & 18 & 29 \\
\hline Croatia & 13 & 35 & 37 \\
\hline Cyprus & 1 & 2 & 53 \\
\hline Czech Republic & 2 & 5 & 70 \\
\hline Denmark & 3 & 8 & 85 \\
\hline Estonia & 1 & 1 & 70 \\
\hline Finland & 4 & 6 & 84 \\
\hline France & 2 & 29 & 78 \\
\hline Germany & 43 & 151 & 73 \\
\hline Greece & 20 & 7 & 47 \\
\hline Hungary & 8 & 8 & 50 \\
\hline Iceland & 2 & 1 & 90 \\
\hline Italy & 17 & 39 & 47 \\
\hline Lithuania & 7 & 69 & 62 \\
\hline Netherlands & 7 & 26 & 84 \\
\hline Norway & 8 & 10 & 86 \\
\hline Poland & 0 & 5 & 54 \\
\hline Portugal & 8 & 16 & 63 \\
\hline Romania & 1 & 15 & 27 \\
\hline Serbia & 8 & 12 & 30 \\
\hline Slovenia & 117 & 1356 & 70 \\
\hline Spain & 23 & 147 & 59 \\
\hline Sweden & 3 & 2 & 85 \\
\hline Switzerland & 12 & 36 & 86 \\
\hline United Kingdom & 198 & 1583 & 75 \\
\hline
\end{tabular}

The data collected in Table 1 were aggregated based on two data sources mentioned above and they refer to all the PTEs (registered on the website museums.eu) realized both in English and in the language of each participant country.

Figure 1 is the graphical representation of the number of PTEs per each country, showing the discrepancies between Slovenia, United Kingdom (UK) and the other countries. 


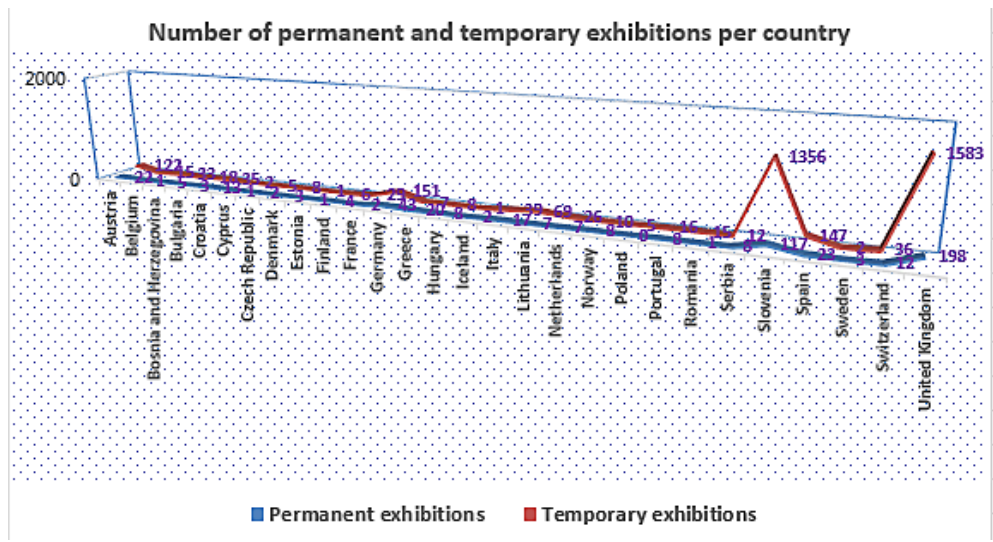

Figure 1. Number of permanent and temporary exhibitions per country (source: created by authors)

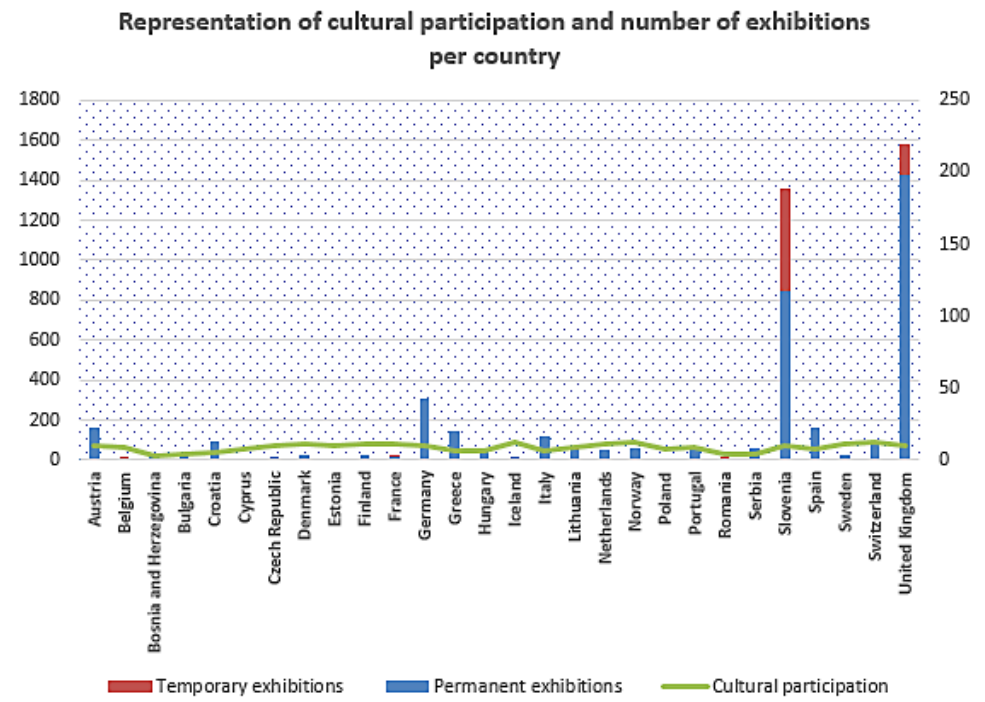

Figure 2. Representation of cultural participation and number of exhibitions per country (source: created by authors)

In Figure 2 both the number of PTEs and the percent of CP per each country are represented. With the current data available, we cannot establish a correlation between the number of exhibitions and the $\mathrm{CP}$ in each country, because the data regarding the number of exhibitions issue only from the CIs registered on museums.eu: The European Museums Network. As we can see, there are countries, such as Slovenia and UK where the number of exhibitions is very high and the percent of $\mathrm{CP}$ is lower than in other countries where the number of exhibitions is insignificant.

We can draw a conclusion regarding the current correlation between the number of PTEs and the percent of $\mathrm{CP}$, showing that the exhibitions realized by different museums and librar- 
ies are insufficiently promoted to the public. If an exhibition is not well publicized, then the number of visitors will be smaller and the cultural collections will not be valorized.

According to Eurostat (2016), another way to monitor CP is to analyze data regarding the use of the Internet, especially from MDs, to purchase cultural goods and services, such as films/music, books/magazines/e-learning material, tickets for cultural and sporting events. Reading online books and e-books was particularly popular in Hungary and Romania, with percentages of at least $25 \%$ of users of the internet via MDs. The official statistics does not cover the problem of using pirated (illegal) cultural productions, because in such a situation the percentages would be higher than mentioned before.

\section{Ferdinand I - an online virtual exhibition}

At The Romanian Academy Library were implemented nine VEs using the MOVIO tool (Athena Plus, 2015), including Ferdinand I, which is available at Biblioteca Academiei Române (2017). These VEs have the objective to promote rare and distinguished collections of the library, in order to make them available to the public and to attract new visitors and interested people or institutions.

In order to measure the users' behavior inside Ferdinand I VE, the Google Analytics indicators were analyzed for the period November 2017 - November 2018. In terms of types of devices used for accessing the VE, the statistics are shown in Table 2.

As seen from Table 2, the number of users that have accessed the online exhibition via laptop or desktop computers is quite similar to the number of users that have accessed the exhibition from their MDs (smartphones and tablets). These numbers are important if we consider that the VE was implemented as a website, using MOVIO, and not as a native mobile application.

In terms of mobile operating system used for accessing the VE, the statistics are presented in Table 3.

Table 2. Number of users by device category (source: created by authors)

\begin{tabular}{|l|c|c|c|}
\hline \multicolumn{1}{|c|}{ Device category } & Number of users & Number of new users & Number of sessions \\
\hline Desktop & 817 & 557 & 979 \\
\hline Mobile & 774 & 521 & 972 \\
\hline Tablet & 20 & 14 & 20 \\
\hline
\end{tabular}

Table 3. Number of users by mobile operating system (source: created by authors)

\begin{tabular}{|l|c|}
\hline \multicolumn{1}{|c|}{ Operating system } & Number of users \\
\hline Android & 499 \\
\hline iOS & 292 \\
\hline Windows Phone & 2 \\
\hline BlackBerry & 1 \\
\hline
\end{tabular}


As displayed in Table 3, Android is the most used mobile operating system. It is interesting that Windows Phone and BlackBerry are still in use, but by very few users.

If we take into account the operating systems for computers, such as Microsoft Windows, Macintosh, Linux, the overall statistics are displayed in Table 4.

Table 4. Number of users by all operating systems (source: created by authors)

\begin{tabular}{|l|c|}
\hline \multicolumn{1}{|c|}{ Operating system } & Number of users \\
\hline Windows & 759 \\
\hline Android & 499 \\
\hline iOS & 292 \\
\hline Macintosh & 34 \\
\hline Linux & 18 \\
\hline
\end{tabular}

If we split the total number of users into desktop and mobile operating systems, we arrive at the same conclusion that the number of users is quite similar in this particular case.

Table 5 presents the total number of users by browser type and includes also the browsers used on MDs. Considering the numbers, Google Chrome is the most used browser, being a universal browser used both on computers and MDs.

Table 5. Number of users by browser type (source: created by authors)

\begin{tabular}{|l|c|}
\hline \multicolumn{1}{|c|}{ Browser } & Number of users \\
\hline Chrome & 1083 \\
\hline Safari & 288 \\
\hline Firefox & 91 \\
\hline Samsung Internet & 42 \\
\hline Edge & 30 \\
\hline Opera & 26 \\
\hline Internet Explorer & 23 \\
\hline Android Webview & 9 \\
\hline Safari (in-app) & 6 \\
\hline Android Browser & 4 \\
\hline
\end{tabular}

The main objective of a VE is to attract new online visitors that could later become real visitors of CIs that preserve the collections presented in the exhibition. This is the reason why we should have statistics about new and returning visitors in the application. As seen from Figure 3, the percent of new visitors is $63 \%$ and the percent of returning visitors is $37 \%$ from the total number of users.

In order to reach new people, the VE should be promoted in different environments. The existing visitors can share information about the VE via social networks or the link to the VE can be placed on the CI website or other main websites where it can be found.

Figure 4 displays the number of users coming from different sources, such as search engines, referral websites, direct link to the VE or social networks. 
As seen in Figure 4, in the case of Ferdinand I VE, the largest number of users is generated by search engines. People made searches about topics and collections presented in the VE and the search engine recommended visiting the exhibition website. It is interesting to see the connection between the events prepared for celebrating the National Day of Romania as well as the 100 years from the consolidation of Romania as a state, and the number of VE accesses. The Ferdinand I VE was dedicated to these events and it included content related to King Ferdinand I of Romania and the union proclamation of provinces forming the actual Romanian state.

By analyzing the number of new users and page accesses from the VE we conclude that it was an increased number of users and accessed pages containing information about these events in the last week of November 2018 (the week before the National Day of Romania).

Figure 5 below presents the graph of the interaction between the pages accessed and the sources the users needed to visit the VE.
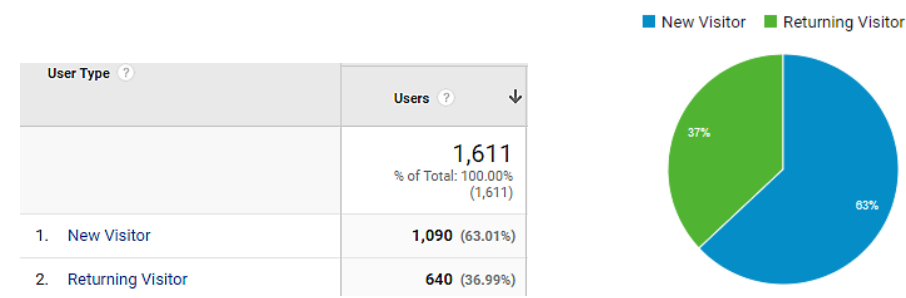

Figure 3. New versus returning visitors (source: created by authors)

\begin{tabular}{|c|c|c|c|c|c|}
\hline & Users & New Users & + & Sessions & \\
\hline & 1,611 & & 1,090 & & 1,971 \\
\hline 1 Organic Search & 1,202 & & & & \\
\hline 2 — Referral & 258 & & & & \\
\hline $3 \square$ Direct & 152 & & & & \\
\hline $4 \square$ Social & 28 & & & & \\
\hline
\end{tabular}

Figure 4. Ways to discover the virtual exhibition (source: created by authors)
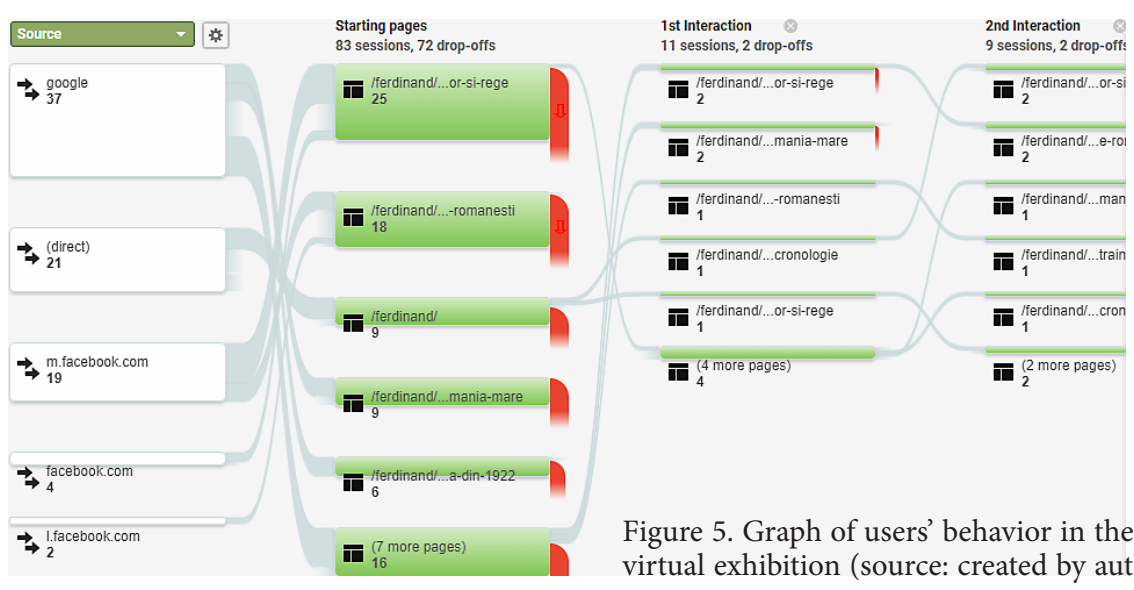

Figure 5. Graph of users' behavior in the virtual exhibition (source: created by authors) 
As shown in Figure 5, from the total of 83 new sessions, a number of 37 originate from Google Search engine, 21 sessions come from direct link access and the remaining 25 sessions come from Facebook sharing the VE.

\section{Metrics to evaluate the virtual exhibitions profitability}

When we want to measure the impact of VEs implementation on the increase of CIs revenues, many aspects and influence factors should be taken into account. There are a lot of indicators that can be measured, such as the number of visitors, the number of items accessed by a user, the time that a user has spent analyzing specific cultural objects, and so on.

Depending on the BM applied by the developers of VEs, we can evaluate how profitable is to implement a VE, in order to make it available to the public. There are different BMs that can be successfully applied in this area, such as Nico Kreinberger, Frank Thinnes, and Nikki Timmermans (2014):

- Advertising revenue model (ARM): is the most applicable BM, which means to insert advertisement in a VE;

- Corporate sponsorships: is the case when a sponsor is providing financially support or by the means of products and services;

- The freemium model (FM): allows users to obtain a free access to the VE and offers additionally features or services against payment;

- Donation-based crowdfunding model: means to receive resources from a community of users, which gets no monetary return of investment; instead the VE can be accessed free of charge.

In the case of ARM, the following indicator can be applied to evaluate the profitability of a new VE:

where:

$$
P M A=N C U \cdot N U \cdot P P C
$$

- PMA - profitability of VE;

- NCU - number of clicks per user on an advertising image (AI);

- NU - total number of users of the VE;

- PPC - price per click on an AI.

Depending on the necessary time to achieve the desired profit, the VE developer can decide which BM to apply. He can choose to apply the $A R M$ or the $F M$, in order to offer additional functionalities against payment.

It is hard to measure exactly the revenues generated by the implementation of a VE, but any increase in CIs revenues is a sign that things are well-done. A mathematical simplified model was proposed and tested on the Bran Castle in Romania in connection with the increasing number of sites addressing Dracula's subject (Bologa, 2002), and a more complex one, which contained a cybernetic representation of cultural entities involved in the processes related to visitors' behavior in a CI, was proposed in (Filip et al., 2017).

In order to measure the degree of knowledge management implied in a VE has, is defined a knowledge management performance indicator (KMPI) as follows (Ciurea, 2009):

$$
K M P I=\frac{K C+K A+K S+K U+K I}{5},
$$


where:

- KC - the knowledge creation indicator in a VE;

- KA - the knowledge accumulation indicator in a VE;

- KS - the knowledge sharing indicator in a VE;

- KU - the knowledge use indicator in a VE;

- KI - the knowledge internalization indicator in a VE.

The KMPI can be a very useful indicator to determine the level of knowledge and information that a VE brought to the visitors and the CIs can make a ranking of VEs developed based on the values of this indicator.

\section{Conclusions}

The main conclusion of this research is that the globalization has influenced all the human activity fields, including the cultural field. The implementation of VEs in museums and libraries will attract new visitors and will increase the general interest of the public in CCs. The evaluation of this phenomenon is in progress. A huge volume of data is collected with a view to quantify the expected effects.

One of the globalization effects is the technological revolution which comes with multiple benefits, especially in the cultural area. Everything has changed, people work and think differently than they did ten years ago, and CIs should be different than before adapted to new visitors' expectations.

Nowadays, the $\mathrm{CH}$ is not only something special to see, to study, to explore, but is considered an economic resource that should generate revenues for CIs, an increase in international visibility and an increase in the number of visitors in all CIs.

In a future research we will address the correlation between the implementation of VEs for a specific CI and its development considering the number of visitors, public visibility and, of course, revenues.

\section{References}

Athena Plus. (2015). MOVIO. Retrieved from http://www.athenaplus.eu/index.php?en/211/movio

Biblioteca Academiei Române. (2017). Ferdinand I Întregitorul Expoziție virtuală. Retrieved from http:// movio.biblacad.ro/FERDINAND/

Bologa, R. (2002). Impactul Internet-ului asupra afluxului de vizitatori spre muzee (Master's Thesis). Bucharest Academy of Economic Studies. Bucharest, Romania [unpublished source].

Borowiecki, K. J., \& Navarrete, T. (2017). Digitization of heritage collections as indicator of innovation. Economics of Innovation and New Technology, 26(3), 227-246. https://doi.org/10.1080/10438599.2016.1164488

Ciurea, C. (2009). A metrics approach for collaborative systems. Informatica Economică, 13(2), 41-49.

Ciurea, C., \& Filip, F. G. (2018). Identifying business models for re-use of cultural objects by using modern ICT tools. Informatica Economică, 22(1), 68-75. https://doi.org/10.12948/issn14531305/22.1.2018.06

Ciurea, C., \& Filip, F. G. (2016). New researches on the role of virtual exhibitions in digitization, preservation and valorization of cultural heritage. Informatica Economică, 20(4), 26-33. https://doi.org/10.12948/issn14531305/20.4.2016.03 
Digital Single Market. (2019). Europe 2020 strategy. Retrieved from https://ec.europa.eu/digital-singlemarket/en/europe-2020-strategy

Eurostat. (2016). Culture statistics: 2016 edition. In J.-L. Mercy \& M. Beck-Domżalska (Eds.), Series: Statistical Books. Retrieved from https://www.culturaydeporte.gob.es/dam/jcr:55160667-7073-4c9e8600-e377168a1fd8/culture-statics2016.pdf

Eurostat. (2018). Culture statistics - cultural participation by socioeconomic background. Statistics explained. Retrieved from https://ec.europa.eu/eurostat/statistics-explained/pdfscache/63357.pdf

Eurostat. (2019). Eurostat. Retrieved from https://ec.europa.eu/eurostat

Filip, F. G., Ciurea, C., Dragomirescu, H., \& Ivan, I. (2015). Cultural heritage and modern information and communication technologies. Technological and Economic Development of Economy, 21(3), 441459. https://doi.org/10.3846/20294913.2015.1025452

Filip, F. G., Zamfirescu, C.-B., \& Ciurea, C. (2017). Computer-supported collaborative decision-making. Series: Automation, Collaboration, \& E-Services. Vol. 4. Berlin, Heidelberg: Springer International Publishing AG. https://doi.org/10.1007/978-3-319-47221-8

Kačerauskas, T. (2015). Technologies in creative economy and creative society. Technological and Economic Development of Economy, 21(6), 855-868. https://doi.org/10.3846/20294913.2015.1036325

Kreinberger, N., Thinnes, F., \& Timmermans, N. (2014). White paper: business models for tourism. Identifying business models for the re-use of cultural objects for tourism. Europeana creative. Retrieved from https://pro.europeana.eu/files/Europeana_Professional/Projects/Project_list/Europeana_Creative/WP3\%20-\%20Business\%20Model\%20Frameworks/eCreative_WP3_White_Paper_ Business_Models_Tourism_v1.0.pdf

Minkov, M. (2011). Cultural differences in a globalizing world. Bingley: Emerald Group Publishing Limited.

museums.eu: The European Museums Network. (2019a). A wealth of exhibitions. Retrieved from http:// museums.eu/exhibition/index

museums.eu: The European Museums Network. (2019b). museums.eu: The European museums network. Retrieved from http://museums.eu/

Spohrer, J. (2018). Perspectives on decision support systems: summary of FG Filip's presentations. Service science. Retrieved from http://service-science.info/archives/5066

Maglio, P. P., \& Spohrer, J. (2008). Fundamentals of service science. Journal of the Academy of Marketing Science, 36(1), 18-20. https://doi.org/10.1007/s11747-007-0058-9

Smithsonian Institution. (2002). Exhibitions and their audiences: actual and potential. Retrieved from https://www.si.edu/content/opanda/docs/rpts2002/02.09.exhibitaudience.final.pdf

Šola, T. S. (2018). Museums and public engagement: four decades of changing concepts and strategies in China. Retrieved from https://www.academia.edu/38088304/Museums_and_public_engagement_ four_decades_of_changing_concepts_and_strategies_in_China

Taylor, J., \& Gibson, L. K. (2017). Digitisation, digital interaction and social media: embedded barriers to democratic heritage. International Journal of Heritage Studies, 23(5), 408-420. https://doi.org/10.1080/13527258.2016.1171245

Vesajoki, F. (2002). The effects of globalization on culture: a study of the experiences of globalization among Finnish travelers (Master's Thesis). Jyväskylä University. Jyväskylä, Finland. Retrieved from https://jyx.jyu.fi/bitstream/handle/123456789/8059/G0000619.pdf

World Values Survey. (2014). Inglehart-Welzel cultural map. Findings and insights. Retrieved from http://www.worldvaluessurvey.org/WVSContents.jsp?CMSID=Findings 


\title{
GLOBALIZACIJOS ITTAKA KÜRYBINĖMS INDUSTRIJOMS IR KULTŪROS PAVELDUI: ATVEJO TYRIMAS
}

\author{
Cristian CIUREA, Florin Gheorghe FILIP
}

\section{Santrauka}

Daugiakultūriškumo, globalizacijos ir technologinès revoliucijos ịtaka meno galerijoms, bibliotekoms, archyvams, muziejams lèmè didžiules kultūros vertybių atrankos, saugojimo, puoselejimo ir vertinimo permainas. Kultūros paveldo kolekcijų skaitmeninimas ir informacijos technologijų (debesų kompiuterijos, mobiliųjų įrenginių, daiktų interneto) raida lèmé virtualių parodų kaip kultūros paveldo fizinių objektų remimo ir vertinimo priemonių pažangą. Siekiant panaudoti bibliotekų ir muziejų kultūros paveldą globalizacijos ir technologinès revoliucijos kontekste, buvo sukurti nauji verslo modeliai ir sukurtos naujos antreprenerystès kategorijos plètros prielaidos. Buvo atlikta tyrimų, siekiant rasti būdų, kaip padidinti kultūros institucijų lankytojų skaičių, naudojant rẻmimo priemones, tokias kaip virtualios parodos ir specialios mobiliosios programèlès. Straipsnyje pristatoma keletas metodologinių aspektų ir praktiniu pavyzdžiu grindžiamos išvados.

Reikšminiai žodžiai: kultūros paveldas, kultūros institucijos, globalizacija, informacijos ir komunikacijos technologijos, ịvertinimas, virtualios parodos. 